\title{
Review of the Septibranchia (Mollusca: Pelecypoda) from the deep sea of Campos Basin, Brazil: Family Lyonsiellidae, with description of a new species
}

\author{
CLÉO DILNEI DE CASTRO OLIVEIRA and RICARDO SILVA ABSALÃO \\ Departamento de Zoologia, Instituto de Biologia, Centro de Ciências da Saúde, Universidade Federal do Rio de Janeiro, \\ Ilha do Fundão, Rio de Janeiro 21941-590, Rio de Janeiro, Brasil.
}

\begin{abstract}
SUMMARY: A review is made of the members of Lyonsiellidae present on the continental slope (750-2000 m) of Campos Basin $\left(22^{\circ} \mathrm{S}\right)$, off south-eastern Brazil. A total of six taxa are recognized. Two taxa were previously unknown to science (Lyonsiella pipoca n. sp., described herein, and Policordia sp.). Lyonsiella frielei and Policordia gemma are recorded from Brazilian waters for the first time. Lyonsiella abyssicola is distributed throughout the Atlantic Ocean, but the present record fills a gap in its distribution in the southwest Atlantic. Lyonsiella cf. formosa has a confused taxonomic status, and we believe that more than one species has been called L. formosa. Lyonsiella abyssicola, L. frielei and $L$. cf. formosa have the shell surface covered by small spines that typically have a hexagonal column and a stellate structure at the distal end.
\end{abstract}

Keywords: Bivalvia, Anomalodesmata, Lyonsiellidae, south-west Atlantic, taxonomy, deep-sea.

RESUMEN: Revisión de los Septibranchia (Mollusca: Pelecypoda) del mar Profundo de la cuenca de Campos, BRASIL: FAMILIA LYONSIELLIDAE, CON DESCRIPCIÓN DE UNA NUEVA ESPECIE. - Se revisan los taxones de la familia Lyonsiellidae encontrados en el talud continental (750-2000 m) de "Cuenca de Campos" (22 ${ }^{\circ}$ ), frente al estado de Rio de Janeiro, Brasil. Dos de estos taxones correspondieron a especies nuevas para la ciencia (Lyonsiella pipoca $\mathrm{n}$. sp., que se describe aquí, y Policordia sp.). Por otro lado, Lyonsiella frielei y Policordia gemma se citan por primera vez en aguas brasileñas. Lyonsiella abyssicola se distribuye por el océano Atlántico, pero la presente cita viene a completar el vacío existente sobre su distribución en el Atlántico suroeste. Otro de los taxones encontrados lo hemos denominado Lyonsiella cf. formosa de forma provisional, pues creemos que la denominación L. formosa se ha aplicado para denominar a más de una especie, por lo que la taxonomía de este supuesto complejo de especies debe ser aclarada. Lyonsiella abyssicola, L. frielei, y L. cf. formosa presentan la superficie de su concha cubierta por pequeñas espinas que típicamente poseen una estructura hexagonal columnar y estrellada en su borde distal.

Palabras clave: Bivalvia, Anomalodesmata, Lyonsiellidae, Atlántico suroeste, taxonomía, mar profundo.

\section{INTRODUCTION}

Lyonsiellidae Dall, 1895 is a family of small pelecypods, which display an anatomical arsenal developed for a carnivorous mode of life. Like most derived septibranchs, the lyonsiellids have an eversible inhalant siphon surrounded by a ring of small tentacles, a sparsely ciliated gut associated with a muscular gizzard stomach with an extensive gastric shield, and gradual muscular development of the ctenidium (Allen and Turner, 1974; Morton, 1987).

The Lyonsiellidae Dall, 1895 was erected as a subdivision of the Verticordiidae Stoliczka, 1871. Bernard $(1974,1979)$ stressed the subdivision of this family into two distinct groups based on anatomical differences among some genera of Verticordiidae (Heilprin, 1881; Smith, 1885; Allen and Turner, 1974; Morton, 1981, 1984, 1987; Prezant and Smith, 
1998). Some databases on European marine fauna (such as the Check List of European Marine Mollusca - CLEMAM database: http://www.somali. asso.fr/clemam/biotaxis.php; European Register of Marine Species: http://www.marbef.org/data/erms. php) include the genus Lyonsiella within the family Verticordiidae and use the genus Allogramma for L. formosa within the family Lyonsiidae. Nevertheless, we follow here the systematic framework proposed by Poutiers and Bernard (1995), Harper et al. (2000), Dreyer et al. (2003) and Morton (2003), which is based on anatomical, morphological and molecular data.

Most lyonsiellids have an almost rectangular shell, usually with the dorso-ventral axis tilted in relation to the antero-posterior axis, instead of the typical perpendicular position of this axis in pelecypods. Moreover, unlike the verticordiids, which usually have a robust shell, the lyonsiellids have a very thin shell and an edentulous hinge.

The Lyonsiellidae have been known since the Pliocene (Harper et al., 2000), and nowadays are present in all deep seas of the world. As in almost all deep-sea species, the number of unnamed species is linked to the difficulties involved in collecting material from great depths. A few studies have dealt with septibranchs in Brazilian waters (e.g. Marini, 1974; Oliveira and Absalão, 2007, 2009; Simone and Cunha, 2008).

This report is part of a continuing effort to fill gaps in the knowledge of the septibranchs, and contains the results of a taxonomic review of the family Lyonsiellidae from Campos Basin, off Rio de Janeiro state, Brazil.

\section{MATERIALS AND METHODS}

One hundred and seventeen samples were taken on the continental slope off south-eastern Brazil $\left(22^{\circ} \mathrm{S}, 41^{\circ} \mathrm{W}\right)$, at depths from 700 to 1950 meters, between 2001 and 2003 as part of the program "Environmental Characterization of Campos Basin, RJ, Brazil" under the auspices of PETROBRAS S.A. The continental slope of Campos Basin is $40 \mathrm{~km}$ wide, with depths up to $3000 \mathrm{~m}$. It is covered by fine sediment and a sandy fraction that is composed mainly of foraminiferan tests (Soares-Gomes et al., 1999). The samples were taken with a $0.25 \mathrm{~m}^{2}$ box corer, from the Research Vessel "Astro-Garoupa". Each sample was washed through a $0.5 \mathrm{~mm}$ mesh, and conserved in $70 \%$ ethanol. In the laboratory, the residues were examined under magnification and the molluscs picked out. Most of the shells were in a good state of conservation, but no live specimens were found.

Each species was photographed under a Scanning Electron Microscope (ZEISS EVO 40), at the Gerência de Bioestratigrafia e Paleoecologia Aplicada (BPA), of the Petrobrás Research Center (Centro de Pesquisas da Petrobrás - CENPES), and under a Scanning Electron Microscope (JEOL - 6390LV) at the Museu Nacional - Universidade Federal do Rio de Janeiro.

The generic characterization was adapted from several authors (e.g. Allen and Turner, 1974; Rios, 1994; Poutiers and Bernard, 1995; Simone and Cunha, 2008). The types of most species treated were examined, except in a few cases when the original illustration and/or description were sufficient to identify the taxon. The material is deposited in the Mollusca collection of the following institutions: Departamento de Zoologia, Instituto de Biologia, Universidade Federal do Rio de Janeiro (IBUFRJ) and Muséum National d'Histoire Naturelle, Paris (MNHN).

\section{RESULTS AND DISCUSSION}

Family Lyonsiellidae Dall, 1895

Type genus: Lyonsiella G.O. Sars, 1872

Diagnosis: Shell small to medium size, inequilateral, umbones central or prosogyrate, outline rounded to quadrate, antero-dorsal indentation almost absent, outer surface smooth or with radial granulations and/ or spines, hinge edentate.

Remarks: Several genera, now allocated within Lyonsiellidae, were previously assigned to Verticordiidae. The verticordiids were subdivided into two groups, Verticordiinae and Lyonsiellinae (Bernard, 1979), mainly on the grounds of anatomical characters, such as the siphonal apparatus and associated musculature (Prezant and Smith, 1998). Some authors (e.g. Bernard, 1979; Morton, 1987; Poutiers and Bernard, 1995) have proposed allocating Policordia Dall, Bartsch and Rehder, 1938, Lyonsiella, and Laevicordia Seguenza, 1876 to a separate family, Lyonsiellidae. Harper et al. (2000), in a cladistic 
TABLE 1. - General characters of the species of Lyonsiella and Policordia. H, height; L, length.

\begin{tabular}{lccccc}
\hline Species & Size range $(\mathrm{mm})$ & Outline & Spine with star-like structure & Pointed spine & Axial threads \\
\hline L. abyssicola & $\mathrm{H}(1-5) ; \mathrm{L}(1-5)$ & Rectangular & Present & Absent & $14-20$ \\
L. frielei & $\mathrm{H}(2-3.5) ; \mathrm{L}(2-4)$ & Quadrangular & Present & Absent & About 15 \\
L. cf. formosa & $\mathrm{H}(2) ; \mathrm{L}(2.5)$ & Rectangular & Present & Very long, smaller near the umbo Absent \\
L. pipoca n. $\mathrm{sp}$. & $\mathrm{H}(1-2) ; \mathrm{L}(1-3.5)$ & Somewhat trapezoidal & Absent & Absent & Absent \\
P. gemma & $\mathrm{H}(1.2-3.5) ; \mathrm{L}(1.2-4)$ & Somewhat triangular or subrounded & Absent & Absent & $15-30$ \\
Policordia sp. & $\mathrm{H}(3) ; \mathrm{L}(2.6)$ & Triangular & Absent & Absent & About 20 \\
& & & & & \\
\hline
\end{tabular}

approach, using 43 anatomical and conchological characters of the subclass Anomalodesmata Dall, 1889 , corroborated this division of Verticordiidae and recognized the family level of Lyonsiellidae. Nevertheless, recent studies have cast doubt on the monophyly of this group (Dreyer et al., 2003).

Table 1 summarizes the characters of Lyonsiellidae treated here.

\section{Genus Lyonsiella G.O. Sars, 1872}

Type species: Lyonsiella abyssicola M. Sars, 1869, nomen nudum. Pecchiolia abyssicola G.O. Sars, 1872, subsequent designation by Soot-Ryen (1966).

Diagnosis: Shell fragile, inflated, umbones prosogyrate, outline somewhat quadrate, dorso-ventral axis angulated, usually ornamented by pustules and/ or spines, often with radial striae. Hinge edentate.

Remarks: One of the most remarkable characteristics of Lyonsiella is the inclination of the anteroposterior axis in relation to the dorso-ventral axis.

Most of species listed by Jeffreys (1881: 930-932) as Lyonsia Turton, 1822 and Pecchiolia Meneghini, 1851 (non G. O. Sars, 1872) proved to be members of Lyonsiella (e.g. Soot-Ryen, 1966; Allen and Turner, 1974; Poutiers and Bernard, 1995). Several genera resemble Lyonsiella, mainly in the outline of the shell, a long and edentate hinge plate, and the presence of pustules or spines. Dall (1886) considered Laevicordia a synonym of Lyonsiella [although, in the opinion of Soot-Ryen (1966), Laevicordia resembles Policordia]. Allen and Turner (1974: 408), although they retained both genera as distinct taxa, noted the similarities between them. Actually, there are no conchological differences that sustain the distinction between Lyonsiella and Laevicordia.

Poutiers and Bernard (1995) and Allen (2008) recognized ten species of Lyonsiella for the Atlantic Ocean (we include here the species treated as Lae- vicordia by one or both authors; these species are marked with “*”): L. subquadrata (Jeffreys, 1881); L. sinuosa* (Jeffreys, 1881); L. smidti* Friele, 1886, nom. nov. pro L. jeffreysi Smith, 1885; L. compressa Allen and Turner, 1974; L. fragilis Allen and Turner, 1974; L. perplexa Allen and Turner, 1974; L. horrida* (Allen and Turner, 1974); L. abyssicola (G. O. Sars, 1872); L. frielei* Allen and Turner, 1974; and $L$. formosa (Jeffreys, 1881). Further details of the distributions of the last three species are given below. Of all these species, only $L$. formosa, $L$. subquadrata, and $L$. smidti have been recorded for Brazil. However, the record of $L$. smidti must be disregarded, because Rios (1994: 305, under the invalid name $L$. jeffreysi) merely repeated the distribution assigned by Smith (1885: 73), who recorded this species from the coordinates $01^{\circ} 47^{\prime} \mathrm{N}, 24^{\circ} 26^{\prime} \mathrm{W}$, which is outside Brazilian territorial waters.

Lyonsiella abyssicola (G.O. Sars, 1872) (Figs. 1A-E)

Pecchiolia abyssicola G.O. Sars, 1872: 25, pl. 3, Fig. 21-43; Jeffreys (1881: 931).

Lyonsiella abyssicola: M. Sars (1869: 257, nomen nudum); Dall (1889: 277); Clarke (1962: 68); Soot-Ryen (1966: 25, pl. 3, Fig. 31); Allen and Turner (1974: 409-432, Figs. 1-25); Poutiers and Bernard (1995: 155); Salas (1996: 80-81, Fig. 151); Allen (2008: 80).

Material examined: BUFRJ 18104 (2207'17’'S, 39॰50'02”'W, $1230 \mathrm{~m}), 13 . \mathrm{V} .02$ [1 valve]; IBUFRJ 18105 (22。3'27'S, $39^{\circ} 45^{\prime} 07^{\prime}$ 'W, $\left.1730 \mathrm{~m}\right), 08 . V .02$ [1 valve]; IBUFRJ 18106 $\left(22^{\circ} 05^{\prime} 45^{\prime}\right.$ 'S, $39^{\circ} 45$ ' $\left.55^{\prime \prime} \mathrm{W}, 1730 \mathrm{~m}\right)$, 09.V.02 [3 valves]; IBUFRJ

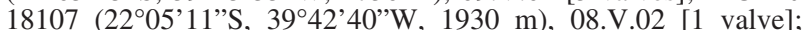
IBUFRJ 18108 (22 $36^{\prime} 47^{\prime}$ 'S, 4009'11'W, $\left.1100 \mathrm{~m}\right), 16 . \mathrm{V} .02$ [2 valves]; IBUFRJ 18109 (22 $2^{\circ} 11^{\prime} 04^{\prime \prime} S, 39^{\circ} 47^{\prime} 04$ ”'W, $\left.1650 \mathrm{~m}\right)$, 25.XI.02 [1 valve]; IBUFRJ 18110 (22 $2^{\circ} 11^{\prime} 16^{\prime \prime} \mathrm{S}, 39^{\circ} 43^{\prime} 44^{\prime \prime} \mathrm{W}$, $1950 \mathrm{~m}), 25 . X I .02$ [2 valves]; IBUFRJ 18111 (2204'44”'S, $39^{\circ} 46^{\prime} 31$ ”'W, $\left.1650 \mathrm{~m}\right), 24 . X I .02$ [1 valve]; IBUFRJ 18112 (2204'46”'S, 39॰43'02”'W, 1950 m), 24.XI.02 [1 valve]; IBUFRJ 18113 (2157'26”S, 39॰40’33”W, $1950 \mathrm{~m}$ ), 11.XII.02 [1 valve];

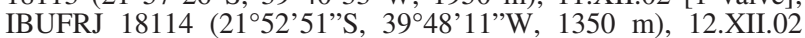
[1 valve]; IBUFRJ 18115 (21 ${ }^{\circ} 52^{\prime} 41^{\prime \prime} \mathrm{S}, 39^{\circ} 46^{\prime} 17^{\prime}$ 'W, $1650 \mathrm{~m}$ ), 11.XII.02 [1 valve]; IBUFRJ 18116 (2152'44”'S, 39॰40'45”'W, $1950 \mathrm{~m}), 11 . X I I .02$ [2 valves]; IBUFRJ 18117 (22。41'35"S, $\left.40^{\circ} 00^{\prime} 45^{\prime \prime} \mathrm{W}, 1950 \mathrm{~m}\right), 22 . X I .02$ [2 valves]; IBUFRJ 18118 (22 ${ }^{\circ} 11^{\prime} 16^{\prime}$ 'S, 39॰43'44”'W, $\left.1950 \mathrm{~m}\right)$, 22.VI.03 [1 valve]; IBUFRJ 18119 (22004'45"S, 39॰46’31"W, 1650 m), 27.VI.03 [3 valves];

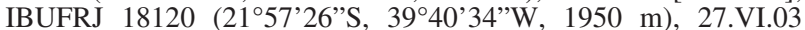
[2 valves]; IBUFRJ 18121 ( $21^{\circ} 52^{\prime} 49^{\prime \prime} \mathrm{S}, 39^{\circ} 51^{\prime} 40^{\prime \prime} \mathrm{W}, 1050 \mathrm{~m}$ ), 28.VI.03 [1 valve]; IBUFRJ 18122 (21 ${ }^{\circ} 52^{\prime} 41^{\prime}$ 'S, 3946'17'”, 


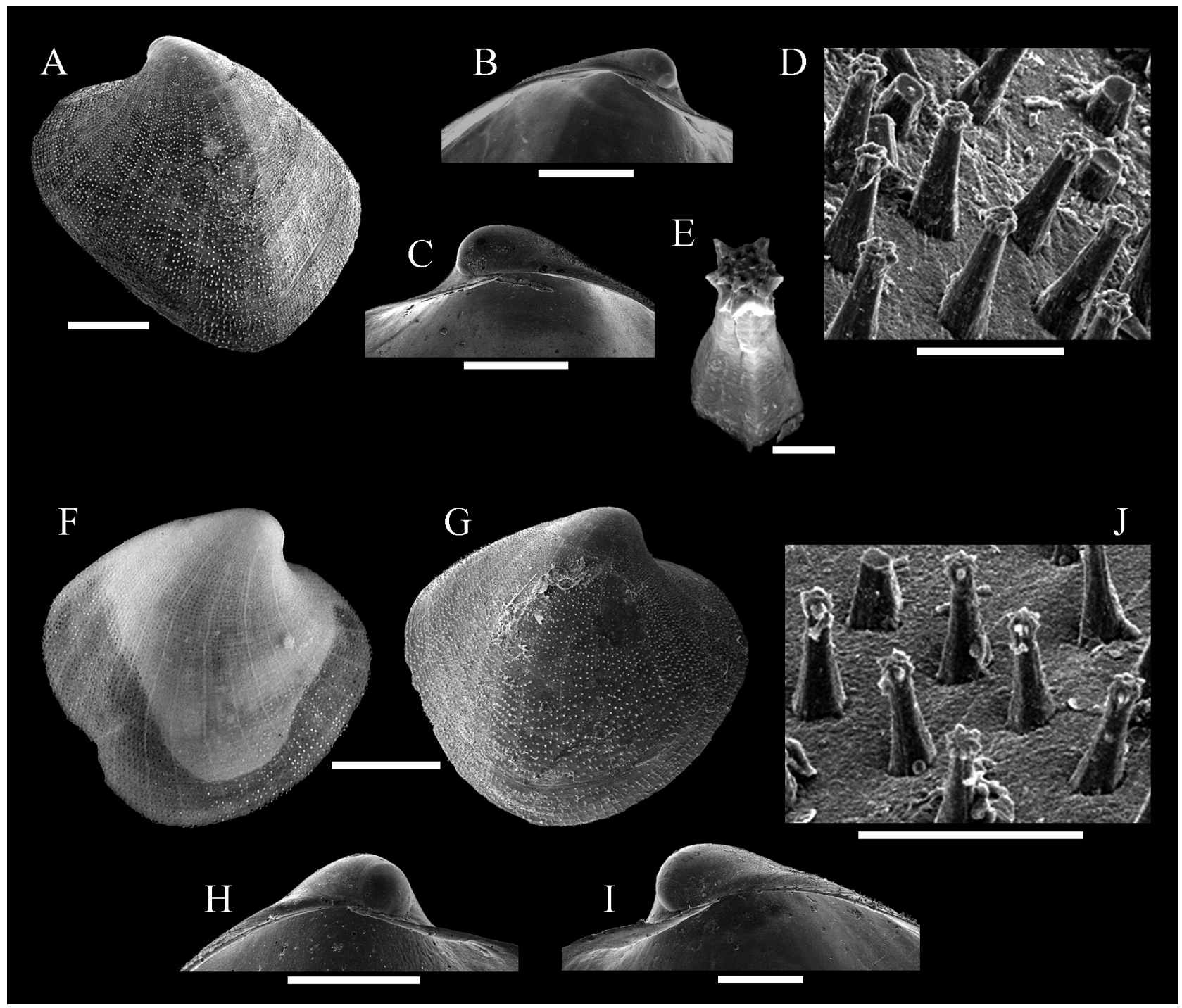

FIG. 1. - Lyonsiella abyssicola (G.O.Sars, 1872): A, external view, left valve, IBUFRJ 14794; B, C, hinge detail, left (IBUFRJ 14794) and right valve (IBUFRJ 18119) respectively; D, external surface detail, IBUFRJ 18115; E, spine detail, IBUFRJ 18115. Lyonsiella frielei Allen and Turner, 1974: F, external view, right valve, holotype MCZ 272672; G, external view, right valve, IBUFRJ 18128; H, I, hinge detail, left (IBUFRJ 18132) and right valve (IBUFRJ 18128) respectively; J, external surface detail, IBUFRJ 18128. Scale Bars: E, $10 \mu \mathrm{m} ; \mathrm{D}, \mathrm{J}, 50 \mu \mathrm{m}$; H, I: $500 \mu \mathrm{m} ; \mathrm{A}-\mathrm{C}, \mathrm{F}, \mathrm{G}, 1 \mathrm{~mm}$.

$1650 \mathrm{~m}), 26 . V I .03$ [2 valves]; IBUFRJ 18123 (215' 43 ”'S, 3940'41’'W, $1950 \mathrm{~m}), 26$. VI.03 [1 valve]; IBUFRJ 18124

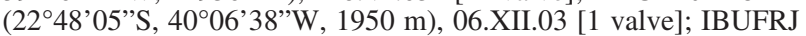
18125 (22॰41’31'S, 4000'47’W, $1950 \mathrm{~m})$, 06.XII.03 [1 valve]; IBUFRJ $18126\left(22^{\circ} 37^{\prime} 02^{\prime \prime} \mathrm{S}, 39^{\circ} 56^{\prime} 20^{\prime}\right.$ 'W, $\left.1950 \mathrm{~m}\right)$, 13.VI.03 [1 valve]; IBUFRJ 18127 (22³0’34”S, 39॰51'44”'W, $1950 \mathrm{~m})$, 16.VI.03 [1 valve].

Description: Shell fragile, white, small (height 1-5 mm, length 1-5 mm), inequivalve, inequilateral, inflated, umbones prosogyrate, outline rectangular, postero-dorsal and antero-ventral margins parallel, almost the same size, postero-ventral margin straight, forming an angle of about $90^{\circ}$ with postero-dorsal and antero-ventral margins, antero-dorsal margin rounded. Externally orna- mented with 14 to 20 fine raised axial threads that intercalate sets of about 5-8 close-set equidistant radiating series of delicate spines. Each spine is a polyhedral column that tapers towards its distal end, which has a stellate, usually hexagonal, structure. The threads extend from the edge of the shell towards the umbo, but do not all reach it. Often exhibiting concentric scars caused by damage. Hinges of both valves edentate, with a slender, posterior groove. The anterior muscle scar is less marked, posterior muscle scar and pallial line hardly visible.

Type locality: Skrova, Lofoten, Norway, 550 m. 
Geographic range: Atlantic Ocean: northwest Atlantic: north (Rosenberg, 2005), west and east of Greenland (Allen and Turner, 1974), southeast of Newfoundland Island, Canada (Soot-Ryen, 1966), Massachusetts, Bermudas (Allen and Turner, 1974). Southwest Atlantic: off Pernambuco (Allen and Turner, 1974), Campos Basin, off Rio de Janeiro (present study), off north Argentina (Allen, 2008). Northeast Atlantic: off the Canary Islands (Allen, 2008), off the Azores (Allen and Turner, 1974), Cape St. Vincent, Ibero-Moroccan Gulf (Salas, 1996), Bay of Biscay, western Ireland (Allen and Turner, 1974; Allen, 2008), English Channel, Spitzbergen to Denmark, Faroes, north coast of Norway (Allen and Turner, 1974), west coast of Norway, Skrova, Lofoten (G.O. Sars, 1872; Allen and Turner, 1974). Bathymetry: from $38 \mathrm{~m}$ to 3909m (Allen and Turner, 1974).

Remarks: The name Lyonsiella abyssicola was introduced by M. Sars (1869), but without a formal description, and it does not comply with article 12 of the Code (ICZN, 2000: 16), and is therefore a nomen nudum. A proper description of this species was provided by G. O. Sars (1872), as Pecchiolia abyssicola.

This species shows some variation in its outline, probably due to a change in the proportions of the shell during ontogeny. The outline of the smallest individuals is sharply angulated, with a truncated aspect, which grades to a trapezoidal outline in adult specimens. In adult specimens, dirt particles encrusted among the spines of the shell are more noticeable.

With regard to the geographical distribution, Allen and Turner (1974: 409) reported that Discovery sta. 6710 was sampled on 19.III.68 at $150^{\circ} 39.6^{\prime} \mathrm{W}$ (near the Hawaiian Archipelago), but it was obviously misprinted, considering that the previous station (Discovery sta. 6709) was sampled on 18.III.68 at $15^{\circ} 20.1^{\prime} \mathrm{W}$ (off the Canary Islands). Probably the correct coordinates of sta. 6710 are $27^{\circ} 23.6^{\prime} \mathrm{N}$, $15^{\circ} 39.6^{\prime} \mathrm{W}$ rather than $150^{\circ} 39.6^{\prime} \mathrm{W}$ as presented by Allen and Turner (1974: 409). This printing error is not insignificant, because of the biogeographical implications.

Lyonsiella frielei Allen and Turner, 1974 (Fig. 1F-J)

Lyonsiella frielei Allen and Turner, 1974: 440-442, Figs. 35, 36; Allen (2008: 80, under the name L. freilei).

Laevicordia frielei: Poutiers and Bernard (1995: 146 and 160, under the name $L$. frieli).
Material examined: IBUFRJ 18128 (2237'54'S, 40¹3'36”'W, $1000 \mathrm{~m}), 19 . \mathrm{V} .02$ [1 valve]; IBUFRJ 18129 (22。11'16”'S, 3943'44”'W, $1950 \mathrm{~m}$ ), 25.XI.02 [4 valves]; IBUFRJ 18130 (22 33'10”S, 39 54'22'W, 1950 m), 23.XI.02 [3 valves]; IBUFRJ 18131 (2204'45”'S, 39॰41'58”W, $1950 \mathrm{~m}), 27 . V I .03$ [1 valve];

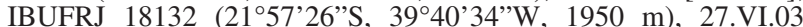
[1 valve]; IBUFRJ 18133 (2241'31'S, 4000'47”W, $1950 \mathrm{~m}$ ), 06.XII.03 [1 valve].

Description: Shell fragile, white, small (height 2-3.5 mm, length 2-4 mm), inequivalve, inequilateral, inflated, umbones prosogyrate, outline quadrangular, postero-dorsal margins sloping downwards, merging with a gently curved ventral margin that is almost continuous with the sharply curved anterodorsal margin, antero-dorsal margin extending slightly below the umbo and forming a short indentation. Externally ornamented with, usually, 15 fine raised axial threads that intercalate with sets of about 4-8 close-set equidistant radiating series of delicate spines. Each spine is a polyhedral column that tapers towards the distal end, which bears a stellate, usually hexagonal structure. The threads extend from the edge of the shell towards the umbo, but do not all reach it. Hinges of both valves edentate. Muscle scars and pallial line hardly visible.

Type locality: Discovery sta. 6714 (off the Canary Islands, $27^{\circ} 13^{\prime} \mathrm{N}, 15^{\circ} 41^{\prime} \mathrm{W}, 3301 \mathrm{~m}$ ) (Allen and Turner, 1974).

Geographic range: Atlantic Ocean: northwest Atlantic: off Barbados (Allen and Turner, 1974). Southwest Atlantic: Campos Basin, off Rio de Janeiro (present study). Southeast Atlantic: Angola (Allen, 2008). Northeast Atlantic: off the Canary Islands (Allen and Turner, 1974; Allen, 2008). Bathymetry: from $1000 \mathrm{~m}$ (present study) to $4429 \mathrm{~m}$ (Allen and Turner, 1974).

Remarks: This species is quite similar to L. abyssicola, and the young specimens of the two species are not easily discriminated. Whereas young specimens of $L$. abyssicola have a sharply angulated shell with a marked and somewhat truncated rectangular outline, young specimens of $L$. frielei have a slightly squared, somewhat rounded outline with the shell length and height almost equal.

Although our specimens diverge from the illustration by Allen and Turner (1974: 441, Fig. 35a), the photograph of the holotype (Fig. 1F) clearly agrees with our material.

The shell of one species from the Indian Ocean, Lyonsiella curta Poutiers, 1984, is very similar to 
that of L. frielei; however, because these taxa are from different oceans, it is very unlikely that they are the same species.

\section{Lyonsiella cf. formosa (Jeffreys, 1881)}

(Fig. 2A-G)

Lyonsia formosa? Jeffreys, 1881: 930, pl. LXX, Fig. 1.

Lyonsiella formosa: Allen and Turner (1974: 447-456, Figs. 43-49), Allen (2008: 80).

Material examined: IBUFRJ 18134 (2241’31’'S, 4000’47’W, $1950 \mathrm{~m}), 06 . X I I .03$ [2 valves].

Description: Shell extremely fragile, white (height $2 \mathrm{~mm}$, length $2.5 \mathrm{~mm}$ ), inequivalve, inequilateral, little inflated, umbones almost central, spiked, blunt, prosogyrate; outline rectangular, postero-dorsal margin almost straight, long, posterior margin truncated, corrugated; ventral margin divided by an axial row of spines that runs from the umbo to the ventral margin; the region between the posterior margin and this axial row is slightly concave, while the region between this axial row and the anterior margin is slightly convex and merges with the rounded anterior margin, antero-dorsal margin curving downward. Covered externally by radiating series of delicate spines. Each spine is a polyhedral column that tapers towards the distal end, which bears a stellate, usually hexagonal, structure. In addition, a series of very long and pointed spines covered by tiny triangular projections extends over the posterior and most of the central parts of the shell; each series of spines grades in size, with the smallest spines nearest the umbo. Each long spine is a hexagonal column with no stellate structure at its distal end. Hinges of both valves edentate. Muscle scars and pallial line hardly visible.

Type locality: Porcupine Expedition 1869: sta. 23 (off Azores); Challenger Expedition (off Gomera, the Canary Islands, 1134 m; off Carysfort, Gulf of Mexico, $638 \mathrm{~m}$ ); Travailleur Expedition (Bay of Biscay, 1010-1097 m).

Geographic range: Atlantic Ocean: northwest Atlantic: off Woods Hole (Allen, 2008), Gulf of Mexico (Jeffreys, 1881; Allen and Turner, 1974). Southwest Atlantic: Mid-Atlantic Ridge (Allen and Turner, 1974; Allen, 2008), Campos Basin, off south-eastern Brazil (present study). Northeast Atlantic: off Guinea-Bissau (Allen, 2008), off the
Canary Islands, Bay of Biscay (Jeffreys, 1881; Allen and Turner, 1974; Allen, 2008), the Azores (Jeffreys, 1881; Allen and Turner, 1974). Bathymetry: from $638 \mathrm{~m}$ (Jeffreys, 1881) to $3783 \mathrm{~m}$ (Allen and Turner, 1974).

Remarks: This species is one of the most beautiful, rare, and fragile septibranch species studied here. Unfortunately, the only specimen collected was broken during the process of taking the SEM photographs. The fragmented shell is shown here (Fig. 2A, B).

This species has a controversial taxonomic history, and in our opinion, different entities have been treated as L. formosa. Jeffreys (1881: 930, pl. LXX, Figs. 1-1a) described Lyonsia formosa from the Atlantic Ocean, from depths of about 640-1134 m. Smith (1885: 72, pl. VI, Figs. 3-3b), although his study was based on material from the same depths and locality as Jeffreys' material, illustrated a quite different species assigned to L. formosa, which is herein termed L. formosa sensu Smith. Whereas in $L$. formosa the axial rib is smooth and disappears towards the ventral margin, in L. formosa sensu Smith, the axial rib is nodulose and continues with the same width from the umbo until it reaches the ventral margin, near the middle of the shell. Furthermore, in L. formosa sensu Smith there are about seven faint furrows, visible externally and internally, that extend obliquely to the anterior margin (see also Salas, 1996: 73, Fig. 102). Such structures are absent in L. formosa. Therefore, in our opinion there are in the Atlantic, at least two different species that have been treated as one. In fact, Locard (1898) attempted to evaluate the variation of characters in L. formosa, and even suggested the presence of two distinct forms (a bathyal and an abyssal form) in the Atlantic Ocean, although he did not elucidate the distinction between the two forms.

Allen and Turner (1974) gave a detailed account of the anatomical characters and recognized this species as a member of the genus Lyonsiella, and also compared their material with Jeffreys' specimens.

Poutiers (1984) obtained specimens similar to Lyonsiella formosa from the Mozambique Channel (11 $\left.{ }^{\circ} 44^{\prime} \mathrm{S}, 47^{\circ} 35^{\prime} \mathrm{E}, 3716 \mathrm{~m}\right)$. Although the exemplar illustrated by Poutiers (1984: 302, Fig. 9) resembles the illustrations of Allen and Turner (1974: 447-456, Figs. 43-49), Poutiers (1984) perceived anatomical differences from Allen and Turner's material, and, because of these differences, termed his species 


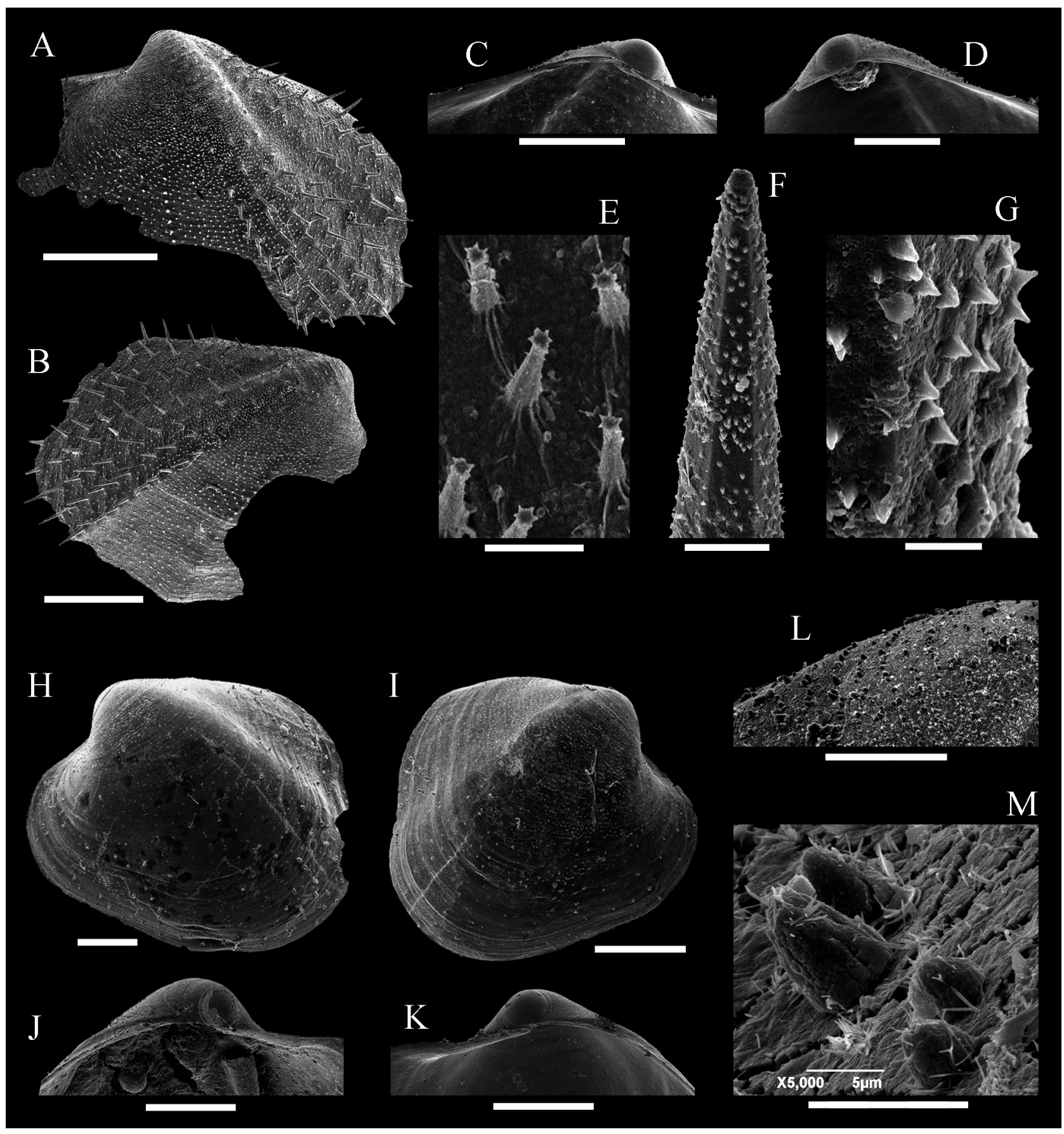

FIG. 2. - Lyonsiella cf. formosa (Jeffreys, 1881), IBUFRJ 18134: A, B, external view, left and right valve respectively; C, D, hinge detail, left and right valve respectively; E, external surface detail; F, longer spine; G, longer spine detail. Lyonsiella pipoca $\mathrm{n}$. sp. Holotype, IBUFRJ 18139: H, I, external view, left and right valve respectively; J, hinge detail, left valve, IBUFRJ 18139; K, hinge detail, right valve IBUFRJ 18140; L, external surface detail, IBUFRJ 18139; M, tiny pyramidal projections, IBUFRJ 18139. Scale Bars: G, $4 \mu \mathrm{m} ; \mathrm{M}, 10 \mu \mathrm{m}$; F, $20 \mu \mathrm{m}$; E, $25 \mu \mathrm{m} ; \mathrm{L}, 100 \mu \mathrm{m} ; \mathrm{H}-\mathrm{K}, 400 \mu \mathrm{m} ; \mathrm{C}, \mathrm{D}, 500 \mu \mathrm{m} ; \mathrm{A}, \mathrm{B}, 1 \mathrm{~mm}$.

Lyonsiella cf. formosa. In addition to the anatomical distinctions between these materials, it seems biogeographically unlikely that specimens from the Indian and Atlantic oceans could belong to the same species.

The species termed Lyonsiella formosa by Morton (1984), who gave a detailed account of the functional morphology of material from Hawaii, is different from the Atlantic L. formosa. The specimen illustrated by Morton (1984: 285, Fig. 1a) has a very short postero-dorsal margin and an extended antero-dorsal margin pointing upwards, and the axial rib, which runs from the umbo to the ventral margin, is markedly acute. In addition, this record 
poses the same biogeographical problem mentioned above.

The record of $L$. formosa from Brazilian waters was given by Allen (2008), based on a record from Allen and Turner (1974) for the Mid-Atlantic ridge (sta. 155: $00^{\circ} 03^{\prime} \mathrm{S}, 27^{\circ} 48^{\prime} \mathrm{W}$; sta. 156: $00^{\circ} 46^{\prime} \mathrm{S}$, $29^{\circ} 28^{\prime} \mathrm{W}$ ). It is clear to us that different taxa were treated under the same name, and that this situation calls for a species revision in the future. Poutiers and Bernard (1995: 169) discussed the generic placement of this controversial species and, like them, we also refrain from adopting any nomenclatural changes until this situation is clarified. We have therefore chosen to treat our specimens as Lyonsiella cf. formosa.

\section{Lysonsiella pipoca $\mathrm{n}$. $\mathrm{sp}$.} (Fig. 2H-M)

Type material: Holotype (IBUFRJ 18139; 2 valves, 08.V.02). Paratype (MNHN; 22 05'11'’S, 3942'40”W, 1930 m, 08.V.02, 1 valve).

Type locality: Campos Basin, south-eastern Brazil (2205'11'S, $\left.39^{\circ} 42^{\prime} 40^{\prime \prime} \mathrm{W}, 1930 \mathrm{~m}\right)$.

Other material examined: IBUFRJ 18135 (2158'36”S, 39 46'30'W, $1700 \mathrm{~m}$ ), 08.X.01 [1 valve]; IBUFRJ 18136 (22 $2^{\circ} 39^{\prime} 34^{\prime \prime} \mathrm{S}, 40^{\circ} 08^{\prime} 22^{\prime}$ 'W, $\left.1200 \mathrm{~m}\right)$, 15.V.02 [1 valve]; IBUFRJ 18137 (2209'10”'S, 3944'50”W, 1930 m), 08.V.02 [1 valve]; IBU-

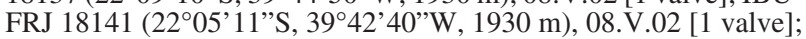
IBUFRJ 18142 (21 $\left.{ }^{\circ} 57^{\prime} 26^{\prime \prime} \mathrm{S}, 39^{\circ} 40^{\prime} 33^{\prime \prime} \mathrm{W}, 1950 \mathrm{~m}\right)$, 11.XII.02 [1 valve]; IBUFRJ 18143 (21 $52^{\circ} 44^{\prime}$ 'S, 39 40’45”'W, $1950 \mathrm{~m}$ ), 11.XII.02 [1 valve]; IBUFRJ 18144 (2236'03”S, 39॰57'54”W, $1650 \mathrm{~m})$, 16.XI.02 [1 valve]; IBUFRJ 18145 (22 41'31's, 4000'47”'W, $1950 \mathrm{~m}), 06 . X I I .03$ [1 valve]; IBUFRJ 18146 $\left(22^{\circ} 36^{\prime} 12^{\prime \prime}\right.$ 'S, 39॰58'22”'W, $\left.1650 \mathrm{~m}\right)$, 13.VI.03 [1 valve]; IBUFRJ 18147 (22³7'02”S, 3956'20”W, $1950 \mathrm{~m}$ ), 13.VI.03 [1 valve]; IBUFRJ 18148 (22³3'08'S, 39॰54'21'W, $1950 \mathrm{~m})$, 15.VI.03 [1 valve].

Description: Shell fragile, white, small (height 1-2 mm, length 1-3.5 mm), inequivalve, inequilateral, inflated, umbones prosogyrate, outline somewhat trapezoidal, postero-dorsal margin descending, forming an angle of about $90^{\circ}$ with postero-ventral margin; a marked indentation of the postero-ventral margin may be present and vary in strength; anteroventral margin rounded, slightly merging with the antero-dorsal margin, which is more or less projected below the umbo and forms a short indentation. Ornamented externally with a series of tiny pyramidal projections, more concentrated near the umbo. A few elongated and very delicate projections may be present over the rest of the shell. Irregular concentric growth lines present. One fine, raised thread runs from the ventral margin to the umbo, but does not reach it. Hinges of both valves edentate. Muscle scars and pallial line hardly visible.
Etymology: This species has been named in relation to its white colour and billowing appearance, which resembles popcorn. Pipoca is a Portuguese word for popcorn that originates from Tupi, the native language of most Brazilian indigenous peoples. The name is employed as a noun in apposition.

Remarks: Lysonsiella pipoca n. sp. may show some variation in outline, mainly in the strength of the indentation at the postero-ventral and antero-dorsal margins. On the postero-ventral margin, the strength of the indentation is a result of the variation in the billowing appearance of the shell, and on the anteroventral margin the strength of the indentation is a direct result of the level of projection of this margin.

Lysonsiella pipoca $\mathrm{n}$. sp. can be distinguished from any other congener in the Atlantic Ocean by its characteristic billowed inflation and somewhat trapezoidal outline. The only species that resembles Lysonsiella pipoca $\mathrm{n}$. sp., although placed in a different genus, is Policordia laevis Allen and Turner, 1974. As the definitions of these genera are not clear-cut, we compare the species here. Both species share the general trapezoidal outline, but $P$. laevis has a sub-central umbo, gently curved posterior margin, and the postero-dorsal margin is little extended and projects slightly more than the postero-ventral margin; whereas in L. pipoca n. sp. the umbo is strongly prosogyrate, the posterior margin is almost straight or slightly sinuous, and the postero-ventral margin is quite extended and more projected than the posterodorsal margin. Moreover, as in all the species in the genus Policordia, P. laevis is devoid of spines or pustules, whereas very small and/or elongated projections are present in L. pipoca n. sp.

Genus Policordia Dall, Bartsch and Rehder, 1938

Type species: Policordia diomedea Dall, Bartsch and Rehder, 1938, by original designation.

Diagnosis: Shell fragile, inflated, umbones prosogyrate, antero-dorsal indentation marked, outline somewhat triangular, ornamented with weakly radiating threads, devoid of pustules or spines. Hinge edentate.

Remarks: Soot-Ryen (1966) recognized 12 species in this genus, most of them previously assigned to Lyonsiella, and this view was followed by subsequent authors (e.g. Allen and Turner, 1974; 
Poutiers and Bernard, 1995). Later, new species and new combinations increased this number to more than 25 (Poutiers and Bernard, 1995). The number of described species in Policordia is probably overstated. The species of this genus are quite similar and the limits of variation among them are not always clear (Smith, 1889; Soot-Ryen, 1966; Allen and Turner, 1974). It would be unsurprising if most of them were found to represent simple variations of the same taxon.

Poutiers and Bernard (1995) and Allen (2008) recognized nine species of Policordia from the Atlantic Ocean: P. gemma (Verrill, 1880), further details about the distribution of this species are given below; P. grandis (Smith, 1885); P. jeffreysi Friele, 1879; P. cordata (Verrill and Bush, 1898); P. densicostata Locard, 1898; P. lisbethae Knudsen, 1970; $P$. atlantica Allen and Turner, 1974; P. insolita Allen and Turner, 1974; and P. laevis Allen and Turner, 1974. Of all these species, only $P$. grandis (reported as Euciroa grandis by Rios, 1994) and P. laevis are recorded for Brazil.

However, the taxon treated by Rios (1994: 304, pl. 104, Fig. 1492) as Euciroa grandis does not concord with the concept of $P$. grandis. Therefore, because the record of this species in Brazilian waters was based on only one lot and this lot does not belong to $P$. grandis, this record must be disregarded.

Policordia gemma (Verrill, 1880) (Fig. 3A-K)

Lyonsiella gemma Verrill, 1880: 396

Pecchiolia insculpta Jeffreys, 1881: 932, pl. LXX, Fig. 4.

Lyonsiella insculpta: Dall (1886: 288).

Policordia gemma: Soot-Ryen (1966: 22, pl. 1, Figs. 8-9, pl. 2, Fig. 24), Allen and Turner (1974: 494-499, Figs. 85-89); Poutiers and Bernard (1995: 160); Salas (1996: 73, 81, Figs. 109-110); Allen (2008: 81).

Material examined: IBUFRJ 14791 (21 ${ }^{\circ} 58^{\prime} 36^{\prime \prime} \mathrm{S}, 39^{\circ} 46^{\prime} 30^{\prime \prime} \mathrm{W}$ 1700 m), 08.X.01 [1 valve]; IBUFRJ 14792 (21 $58^{\circ} 36^{\prime \prime} \mathrm{S}$, 39॰46’30"W, $1700 \mathrm{~m})$, 08.X.01 [1 valve]; IBUFRJ 18149 (22 33'08'S, 39 54'21'W, $1950 \mathrm{~m}), 15 . \mathrm{VI} .03$ [2 valves]; IBUFRJ 18150 (22 33'08'S, 39॰54'21'W, $1950 \mathrm{~m}), 15 . \mathrm{VI} .03$ [1 valve]; IBUFRJ 18151 (22॰11'16”S, 39॰43'44”'W, $1950 \mathrm{~m})$, 22.VI.03 [1 valve]; IBUFRJ 18152 (21 $57^{\circ} 26^{\prime}$ 'S, 39॰40'34'W, $1950 \mathrm{~m}$ ), 27.VI.03 [1 valve]; IBUFRJ 18153 (21 ${ }^{\circ} 57^{\prime} 26^{\prime \prime} \mathrm{S}, 39^{\circ} 40^{\prime} 34^{\prime \prime} \mathrm{W}$ $1950 \mathrm{~m}), 27 . V I .03$ [1 valve]; IBUFRJ 18154 (2152'41'S $\left.39^{\circ} 46^{\prime} 17^{\prime} \mathrm{W}, 1650 \mathrm{~m}\right), 26 . V I .03$ [1 valve]; IBUFRJ 18155 (21 52'43'S, 3940'41'W, $1950 \mathrm{~m}), 26 . \mathrm{VI} .03$ [3 valves]; IBUFRJ 18156 (22 48'05'S, 4006'38'W, $1950 \mathrm{~m}$ ), 06.XII.03 [4 valves]; IBUFRJ $18157\left(22^{\circ} 41^{\prime} 31\right.$ 'S, 40 $\left.0^{\circ} 00^{\prime} 47^{\prime \prime} \mathrm{W}, 1950 \mathrm{~m}\right)$, 06.XII.03 [5 valves]; IBUFRJ 18158 (22 $36^{\circ} 12^{\prime}$ 'S, 39'58'22'W, $1650 \mathrm{~m}$ ), 13.VI.03 [1 valve]; IBUFRJ 18159 (22 $28^{\circ} 46^{\prime \prime} \mathrm{S}, 39^{\circ} 53$ '27'W, $1650 \mathrm{~m})$, 17.VI.03 [1 valve]; IBUFRJ 18160 (22 $30^{\circ} 34^{\prime \prime} \mathrm{S}$, 39॰51'44"'W, $1950 \mathrm{~m}$ ), 16.VI.03 [2 valves]; IBUFRJ 18161 (2230'34”'S, 39॰51'44''W, $1950 \mathrm{~m}$ ), 16.VI.03 [2 valves]; IBUFRJ 18162 (22 $\left.39^{\circ} 44^{\prime \prime} \mathrm{S}, 40^{\circ} 15^{\prime} 44^{\prime \prime} \mathrm{W}, 1000 \mathrm{~m}\right), 19 . \mathrm{V} .02$ [1 valve]; IBUFRJ $18163\left(22^{\circ} 39^{\prime} 44^{\prime} \mathrm{S}, 40^{\circ} 15^{\prime} 44^{\prime \prime} \mathrm{W}, 1000 \mathrm{~m}\right), 19 . \mathrm{V} .02$ [1 valve]; IBUFRJ 18164 (22 39 '44”'S, 40¹5'44”'W, $1000 \mathrm{~m})$,
19.V.02 [1 valve]; IBUFRJ 18165 (22॰04'44”'S, 39॰46’31'"W, 1650 m), 24.XI.02 [1 valve]; IBUFRJ 18166 (21 $57^{\circ} 26$ ”'S, 39॰40'33”'W, 1950 m), 11.XII.02 [1 valve]; IBUFRJ 18167 (21 ${ }^{\circ} 57^{\prime} 26^{\prime \prime} \mathrm{S}$, 39॰40’33”'W, $1950 \mathrm{~m}$ ), 11.XII.02 [1 valve]; IBUFRJ 18168 (2246'59”'S, 40॰07'49”'W, 1650 m), 22.XI.02 [1 valve]; IBUFRJ 18169 (22 $\left.2^{\circ} 03^{\prime} 27^{\prime \prime} \mathrm{S}, 39^{\circ} 45^{\prime} 07^{\prime \prime} \mathrm{W}, 1730 \mathrm{~m}\right)$, 08.V.02 [4 valves]; IBUFRJ $18170\left(22^{\circ} 09^{\prime} 10^{\prime \prime S}, 39^{\circ} 44^{\prime} 50^{\prime \prime W}, 1930 \mathrm{~m}\right), 08 . \mathrm{V} .02$ [3 valves]; IBUFRJ 18171 (2206'52”S, 39॰44'13”'W, $1930 \mathrm{~m}$ ),

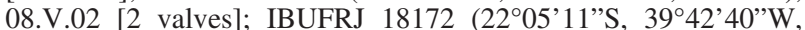
$1930 \mathrm{~m}), 08$. V.02 [1 valve].

Description: Shell fragile, white, small (height 1.2-3.5 mm, length 1.2-4 mm), inequivalve, inequilateral, little inflated, umbones prosogyrate, outline subtriangular or subcircular, postero-dorsal margin nearly straight, descending, more or less angled with the U-shaped ventral margin, antero-dorsal margin rounded, little projected below the umbo. Ornamented externally with about 15-30 axial threads, faintly concentric growth lines present. Hinges of both valves edentate. Muscle scars and pallial line hardly visible.

Type locality: Fish Hawk sta. 892 (Newport, United Kingdom, 820 m) (Verrill, 1880).

Geographic range: Atlantic Ocean: northwest Atlantic: southeast of Newfoundland Island, Canada (Soot-Ryen, 1966), off Woods Hole (Allen and Turner, 1974; Allen, 2008). Southwest Atlantic: MidAtlantic Ridge (Allen and Turner, 1974; Allen, 2008), Campos Basin, off south-eastern Brazil (present study), Argentina (Allen and Turner, 1974; Allen, 2008). Southeast Atlantic: Namibia (Allen and Turner, 1974). Northeast Atlantic: off the Canary Islands, the Azores (Allen and Turner, 1974), off Rabat, IberoMoroccan Gulf, Cape St. Vincent, Ibero-Moroccan Gulf (Salas, 1996), Bay of Biscay (Jeffreys, 1881; Allen, 2008), off Brest, western France (Allen, 2008), Newport, United Kingdom (Verrill, 1880), western Ireland (Allen, 2008). Mediterranean Sea: eastern Ceuta, Alboran Sea (Salas, 1996), Palermo (Jeffreys, 1881). Bathymetry: from 73 m (Poutiers and Bernard, 1995) to $3917 \mathrm{~m}$ (Allen and Turner, 1974).

Remarks: This species varies greatly in outline, and no clear limits can be established among allegedly distinct taxa. There are several differences among the specimens, including the number of axial threads, the convexity and extension of the posteroanterior margin, the angle formed by the margins, and the strength of the umbo. Certainly, samples of only a few specimens may be classified erroneously, and because of the large number of specimens ex- 


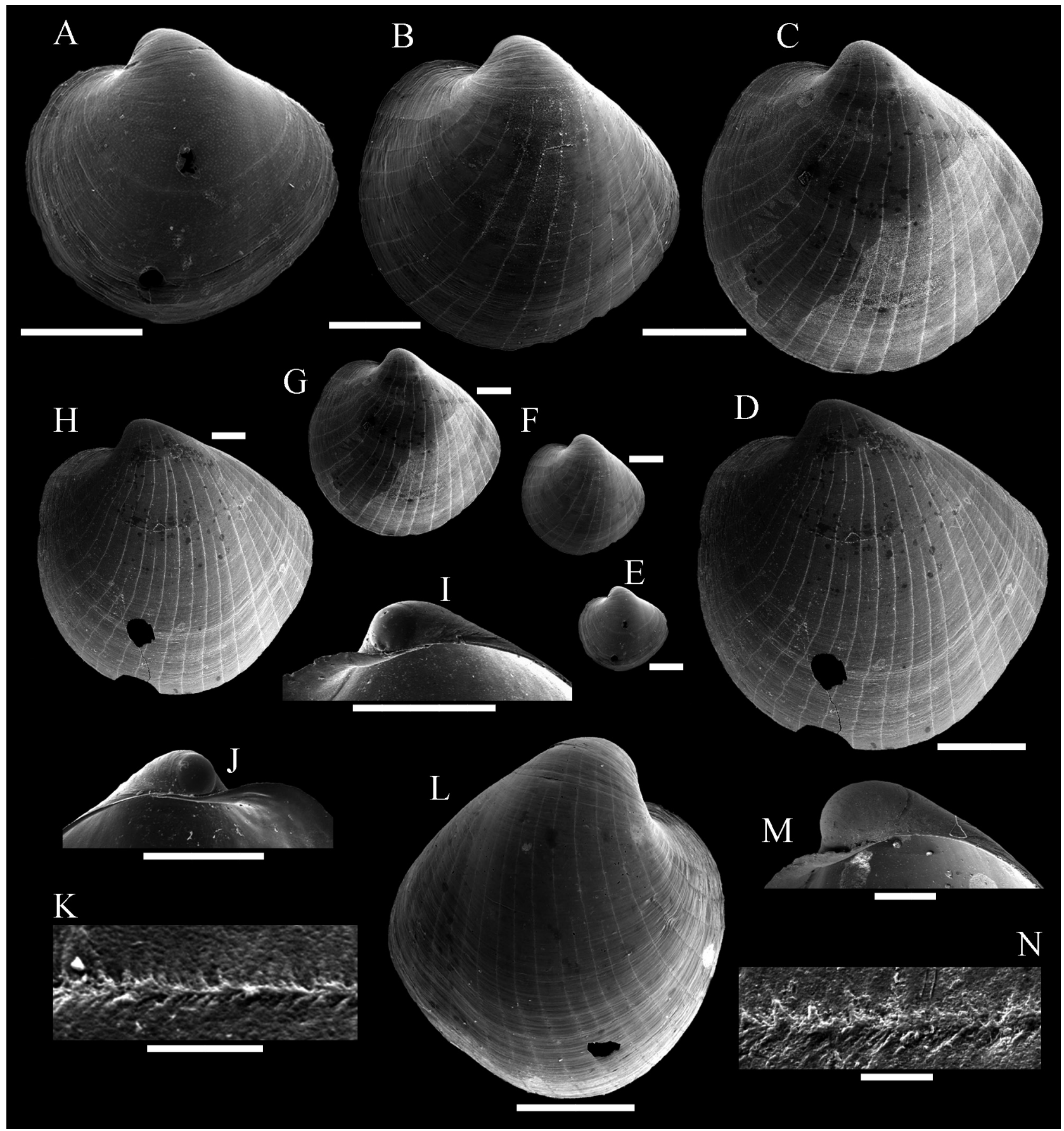

FIG. 3. - Policordia gemma (Verrill, 1880): A, E, external view, left valve, IBUFRJ 18245; B, F, external view, left valve, IBUFRJ 14790; C, G, External view, left valve, IBUFRJ 18162; D, H, external view, left valve, IBUFRJ 18163; I, J, hinge detail, right (IBUFRJ 14791) and left valve (IBUFRJ 14790) respectively; K, radial lines detail, IBUFRJ 14792. Policordia sp., IBUFRJ 14791: L, external view, right valve; M, hinge detail, right valve; N, radial lines detail. Scale Bars: K, N, $20 \mu \mathrm{m} ; \mathrm{A}, \mathrm{B}, \mathrm{E}-\mathrm{J}, \mathrm{M}, 500 \mu \mathrm{m} ; \mathrm{C}, \mathrm{D}, \mathrm{L}, 1 \mathrm{~mm}$.

amined for the present study, it is clear to us that establishing consistent differences among populations is an almost impossible task. Thus, from the conchological point of view, only one species, $P$. gemma, can be recognized here.

Allen and Turner (1974: 478) indicated the difficulty in distinguishing three species, P. gemma, $P$. densicostata (Locard, 1898), and P. atlantica Allen and Turner, 1974, using shell characters alone. They suggested a classification based on an additional diagnostic character, i.e. the appearance of the radiating lines, because these lines can be slightly raised in P. gemma and P. densicostata, or shallow furrows in $P$. atlantica. It is difficult to discriminate these 
species on the basis of this character. Our specimens have raised lines.

Allen (2008) recorded this species from the Brazilian Basin, analyzing the same stations as Allen and Turner (1974); however, Allen and Turner (1974) recorded $P$. gemma from the Mid-Atlantic ridge (sta. 156: $00^{\circ} 46^{\prime} \mathrm{S}, 29^{\circ} 28^{\prime} \mathrm{W}$ ), which is far from the Brazilian coast. In addition, Allen (2008) reported the occurrence of this species in the Angola Basin, but this record is not corroborated by the stations he listed in Appendix 3 (p. 163-169). Therefore, until this point can be clarified, this occurrence must be viewed with caution.

\section{Policordia sp.}

(Fig. 3L-N)

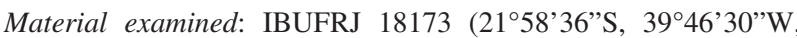
$1700 \mathrm{~m}), 08 . X .01$ [1 valve].

Description: Shell fragile, white, small (height 3 $\mathrm{mm}$, length $2.6 \mathrm{~mm}$ ), inequivalve, inequilateral, very inflated, umbones prosogyrate, outline triangular, postero-dorsal margin straight, descending, forming an angle of about $90^{\circ}$ with postero-ventral margin, ventral margin strongly angled, gently merging with a low antero-dorsal margin. Ornamented externally with about 20 axial threads, faintly concentric growth lines present. Hinge of right valve edentate. Muscle scars and pallial line hardly visible.

Remarks: Policordia gemma shows a great variation in outline, but Policordia sp. does not fit into the range of this variation. Policordia sp. has a larger umbo, a noticeably more convex valve, a slight indentation on the posterior margin, and more axial threads than specimens of $P$. gemma of the same size.

Although Policordia sp. is probably new to science, to avoid an increase in unwarranted, closely similar species, a formal description is delayed until enough specimens are collected to allow us to evaluate the possible variation and limits of Policordia sp.

\section{GENERAL REMARKS}

One kind of external ornamentation, a spine with a stellate structure near its distal end, is present in almost all the species of Lyonsiella treated here. This structure was observed in verticordiids from Cam- pos Basin, and may reinforce the affinities between Verticordiidae and Lyonsiellidae.

Another kind of ornamentation, an ornamented pointed spine with no stellate structure at the distal end (Fig. 1E), is present in Lyonsiella cf. formosa. Such a structure has not been observed for any $L y$ onsiella species. Lyonsiella pipoca $\mathrm{n}$. sp. is unique among the genera and species examined here because it does not have spines with a stellate structure. Policordia, typically for the genus, has no spines or pustules, but rather raised axial threads.

Because the shell ornamentation is an important character in pelecypod taxonomy, the typical shell ornamentation of the species treated herein may contribute to the discussion on the monophyly of lyonsiellids (e.g. Dreyer et al., 2003).

\section{ACKNOWLEDGEMENTS}

Our best thanks are to Dr. John Allen (University Marine Biological Station) for his encouragement, exchange of ideas, bibliography and critical information on all aspects of this work; to Dr. Templado (Museo Nacional de Ciencias Naturales) and to the reviewers Dr. Bieler (Field Museum of Natural History) and Dr. Gofas (University of Málaga) for their criticisms and suggestions that improved this manuscript; to Dr. Janet Reid for the final English revision of this manuscript, and to PETROBRAS (Brazilian Petroleum Co.) for making this material available and for SEM support. This research was partially supported by fellowships from FAPERJ (Fundação de Amparo a Pesquisa do Estado do Rio de Janeiro) and $\mathrm{CNPq}$ (Conselho Nacional de Desenvolvimento Científico e Tecnológico).

\section{REFERENCES}

Allen, J.A. - 2008. Bivalvia of the deep Atlantic. Malacologia, 50: 57-173.

Allen, J.A. and J.F. Turner. - 1974. Functional morphology of family Verticordiidae (Bivalvia) with descriptions of new species from Abyssal Atlantic. Philos. Trans. R. Soc. Lond. B, 268: $401-536$.

Bernard, F.R. - 1974. Septibranchs of the eastern Pacific (Bivalvia Anomalodesmata). Allan Hancock Foundation, University of Southern California, Los Angeles.

Bernard, F.R. - 1979. New species of Cuspidaria from the Northeastern Pacific (Bivalvia: Anomalodesmata), with a proposed classification of septibranchs. Venus, 38: 14-24.

Clarke, A.H. - 1962. Annotated List and Bibliography of the Abyssal Marine Molluscs of the World. Dept. of Northern Affairs and National Resources, Ottawa.

Dall, W.H. - 1886. Report on the Mollusca. Part 1. Brachiopoda and 
Pelecypoda. Reports on the results of dredging by the US coast survey steamer 'Blake'. Bull. Mus. Comp. Zool., 12: 171-318.

Dall, W.H. - 1889. A preliminary catalogue of the shell bearing marine mollusks and brachiopods of the S.E. coast of the United States. Bull. U.S. Natl. Mus., 37: 1-221.

Dreyer, H., G. Steiner and E.M. Harper. - 2003. Molecular phylogeny of Anomalodesmata (Mollusca: Bivalvia) inferred from 18S rRNA sequences. Zool. J. Linn. Soc., 139: 229-246.

Harper, E.M., E.A. Hide and B. Morton. - 2000. Relationships between the extant Anomalodesmata: a cladistic test. In: E.M. Harper, J.D. Taylor and J.A. Crame (eds.), The Evolutionary Biology of the Bivalvia, pp. 129-143. Geological Society of London Special Publications, London.

Heilprin, A. - 1881. Remarks on the Molluscan Genera Hippagus, Verticordia and Pecchiolia. Proc. Acad. Nat. Sci. Phila., 33: 423-428.

ICZN. - 2000. International Code of Zoological Nomenclature. International Trust for Zoological Nomenclature.

Jeffreys, J. - 1881. On the Mollusca procured during the Lightning and Porcupine expeditions, 1868-70. Part. IV. Proc. Zool. Soc. Lond., 922-952.

Locard, A. - 1898. Expéditions Scientifiques du Travailleur et du Talisman Pendant les Années 1880, 1881, 1882, 1883. Mollusques testacés, 2: 1-515.

Marini, A. - 1974. O gênero Verticordia Wood, 1844 (Bivalvia, Verticordiidae) na plataforma continental brasileira. Pap. avulsos. zool., 28: 241-244.

Morton, B. - 1981. The Anomalodesmata. Malacologia, 21: 35-60.

Morton, B. - 1984. Prey capture in Lyonsiella formosa (Bivalvia: Anomalodesmata: Verticordiacea). Pac. Sci., 38: 283-297.

Morton, B. - 1987. Siphon structure and prey capture as a guide to affinities in the abyssal septibranch Anomalodesmata. Sarsia, 72: 49-69.

Morton, B. - 2003. The functional morphology of Bentholyonsia teramachii (Bivalvia: Lyonsiellidae): clues to the origin of predation in the deep water Anomalodesmata. J. Zool., 261, 363-380.

Oliveira, C.D.C. and R.S. Absalão. - 2007. Primeiro registro de Mendicula ferruginosa, Kelliella atlantica e Lyonsiella subquadrata (Mollusca, Pelecypoda) para águas brasileiras. Biociências, 15: 63-67.

Oliveira, C.D.C. and R.S. Absalão. - 2009. The Genera Myonera, Octoporia and Protocuspidaria (Mollusca, Pelecypoda, Cuspidariidae) from Deep Waters of Campos Basin, Rio de Janeiro, Brazil, with descriptions of two new species. Am. Malacol. Bull., 27: 141-156.

Poutiers, J. - 1984. Septibranches abyssaux de l'océan Indien occidental (Mollusques Bivalves Anomalodesmata). J. conchol., 31: $281-306$.
Poutiers, M. and F.R. Bernard. - 1995 Carnivorous bivalve molluscs (Anomalodesmata) from the tropical western Pacific Ocean, with a proposed classification and a catalogue of Recent species. Mem. Mus. Natl. Hist. Nat., 167: 107-187.

Prezant, R.S. and B.J. Smith. - 1998. Subclass Anomalodesmata. In: P.L. Beesley, G.J.B. Boss and A. Wells (eds.), Mollusca: the southern synthesis. Fauna of Australia, pp. 327-429.

Rios, E. - 1994. Seashells of Brazil. Fundação Universidade do Rio Grande, Rio Grande.

Rosenberg, G. - 2005. Malacolog 4.1.0: A Database of Western Atlantic Marine Mollusca. [WWW database (version 4.1.0)] URL http://www.malacolog.org/.

Salas, C. - 1996. Marine Bivalves from off the Southern Iberian Peninsula collected by the Balgim and Fauna 1 expeditions. Haliotis, 25: 33-100.

Sars, G.O. - 1872. On some remarkable forms of animal life from the great deeps off the Norwegian coast, 1. Partly posthumous manuscripts of the late Professor Dr. Michael Sars. University prog. $1^{\text {st }}$ half year, Christiania. Brogger and Christie.

Sars, M. - 1869. Forsatte bemaerkninger om det dyriske livs udbredning i havets dybder. Forhandlinger vid det Videnskablige Selskab i Christiania, 1868: 246-275.

Simone, L.R.L. and C.M. Cunha. - 2008. Revision of the genus Spinosipella (Bivalvia: Verticordiidae), with descriptions of two new species from Brazil. Nautilus, 122: 182-182.

Smith, E. - 1885. Report on the Lamellibranchiata collected by HMS Challenger during the years 1873-1876. Rep. scient. Res. Challenger, 13: 1-341.

Smith, E.A. - 1889. Mollusca. Report of a deep sea trawling cruise off the south west coast of Ireland under the direction of Rev. W. Spotswood Green, M.A., F.R.G.S. Ann. mag. nat. hist., 6: 420-425.

Soares-Gomes, A., C.M.R.C. Abreu, T.M. Absher and A.G. Figueiredo. 1999 - Abiotic features and the abundance of macrozoobenthos of continental margin sediments of East Brazil. Mar. Ecol. Prog. Ser., 127: 113-119.

Soot-Ryen, T. - 1966. Revision of the pelecypods of Mikael Sars North Atlantic Deepsea expedition 1910 with notes on the family Verticordiidae and other interesting species. Sarsia, 24: 1-31.

Verrill, A.E. - 1880. Notice of Recent Additions to the Marine Invertebrata of the Northeastern Coast of America, with Descriptions of New Genera and Species and Critical Remarks on Others. with Notes on Annelida, Echinodermata, etc., collected by the United States Fish Commission. Proc. U.S. Natl. Mus., 3: $356-409$.

Scient. ed.: J. Templado.

Received March 19, 2009. Accepted July 16, 2009.

Published online March 8, 2010. 